\title{
Low Bordetella pertussis Antibody Seroprevalence Among Mothers and Infants
}

\section{Annelerde ve Bebeklerde Düşük Bordetella pertussis Antikor Seroprevalansı}

\author{
Bahar Kural $^{1 \oplus}$, Perran Boran ${ }^{2} \oplus$, Esra Devecioglu Karapinar ${ }^{3 \oplus}$, Gulbin Gokcay $^{4} \odot$, Tijen Eren $^{5} \odot$ \\ Selim Badur ${ }^{6} \oplus$, Gonca Yilmaz ${ }^{7}$ \\ ${ }^{1}$ Department of Pediatrics, Bakirköy Dr. Sadi Konuk Research and Training Hospital, Istanbul, Turkey \\ ${ }^{2}$ Department of Pediatrics, Division of Social Pediatrics, Marmara University Faculty of Medicine, Istanbul, Turkey \\ ${ }^{3}$ Department of Social Pediatrics, Istanbul University Institute of Child Health, Istanbul, Turkey \\ ${ }^{4}$ Department of Pediatrics, Istanbul University Istanbul Medical School, Istanbul, Turkey \\ ${ }^{5}$ Department of Pediatrics, Koç University Faculty of Medicine, Istanbul, Turkey \\ ${ }^{6}$ Emeritus from Istanbul Faculty of Medicine, Department of Medical Microbiology, Istanbul, Turkey \\ ${ }^{7}$ Department of Pediatrics, Dr. Sami Ulus Childrens' Hospital, Ankara, Turkey
}

Received: 4 April 2020 / Accepted: 11 May 2020 / Publication date: 26 June 2020

Cite as: Kural B, Boran P, Devecioglu Karapinar E, Gokcay G, Eren T, Badur S, Yilmaz G. Low Bordetella pertussis antibody seroprevalence among mothers and infants. Med J Bakirkoy 2020;16(2):103-7.

\section{ABSTRACT}

Objective: The greatest risk of morbidity and mortality from pertussis infection is observed among infants who are 6 months and younger. Therefore protection from pertussis infection is very important during the first 6 months of life. The aim of the study is to assess Bordetella pertussis antibody titers among infants after two doses of pertussis vaccination at 6 months of age.

Method: This was a prospective, multicentered cohort study. Paired maternal and infant serum samples were obtained during the first month after delivery and only infant serum samples were again taken at 6 months of age. Serum samples were tested for Bordetella pertussis-IgG by the enzyme-linked immunosorbent assay (ELISA).

Results: The study enrolled 209 mother-infant pairs. At one month after delivery $49.7 \%$ of mothers and $32.1 \%$ of infants had detectable Bordetella pertussis-IgG antibodies. After two doses of DTaP-IPV-Hib vaccine, at 6th months of age, Bordetella pertussisIgG seroprevalence among infants increased to $43.3 \%$.

Conclusion: After 2 doses of DTaP-IPV-Hib, more than half of the infants at 6 months of age had undetectable Bordetella pertussis-IgG and presumed unprotected against pertussis disease. A new strategy of protecting infants from pertussis must be implemented.

Keywords: pertussis, maternal antibody, infant antibody, seroconversion

Öz

Amaç: Altı aylık ve daha küçük bebekler boğmaca enfeksiyonundan en yüksek morbidite ve mortalite riskine sahiptirler. Bu nedenle boğmaca enfeksiyonundan korunma, yaşamın ilk 6 ayında çok önemlidir. Bu çalışmanın amacı, bebeklerde Bordetella pertussis antikor titrelerini 6 aylıkken iki doz boğmaca aşılamasından sonra değerlendirmektir.

Yöntem: Bu bir prospektif, çok merkezli kohort çalıșmasıdır. Doğumdan sonraki ilk ayda anne ve bebek çiftlerinden serum örnekleri alındı ve yine sadece bebek serum örnekleri 6 aylıkken alındı. Serum numuneleri, enzime bağlı immünosorban analizi (ELISA) ile Bordetella pertussis-IgG için test edildi.

Bulgular: Çalışmaya 209 anne-bebek çifti alındı. Doğumdan bir ay sonra annelerin \% 49,7'si ve bebeklerin \% 32,1'i saptanabilir Bordetella pertussis-IgG antikorlarına sahipti. Iki doz DTaP-IPV-Hib aşısından sonra, 6. aylıkken, bebeklerde Bordetella pertussis-IgG seroprevalansı \% 43,3'e yükseldi.

Sonuç: iki doz DTaP-IPV-Hib aşıSı sonrasında, 6 aylık bebeklerin yarısından fazlasında Bordetella pertussis-IgG saptanmadı ve bunların boğmaca hastalığına karşı korumasız olduğu varsayıldı. Bebekleri boğmacadan korumak için yeni bir strateji uygulanmalıdır.

Anahtar kelimeler: boğmaca, anneye ait antikor, bebeğe ait antikor, serokonversiyon

Corresponding Author:

drbahsal@yahoo.com
B. Kural 0000-0001-9528-1009

P. Boran 0000-0002-9885-7656

E. D. Karapinar 0000-0003-4679-7513

G. Gokcay 0000-0003-1042-0407
T. Eren 0000-0001-9650-3734

S. Badur 0000-0002-1316-6259

G. Yilmaz 0000-0003-2242-5416

(c) Telif hakkı Sağık Bilimleri Üniversitesi Bakırköy Dr. Sadi Konuk Eğitim ve Araştırma Hastanesi'ne aittir. Logos Tıp Yayıncılık tarafindan yayınlanmaktadır. Bu dergide yayınlanan bütün makaleler Creative Commons Atff-GayriTicari 4.0 Uluslararası Lisansı ile lisanslanmıştır.

C Copyright Health Sciences University Bakırköy Sadi Konuk Training and Research Hospital. This journal published by Logos Medical Publishing.

Licenced by Creative Commons Attribution-NonCommercial 4.0 International (CC BY-NC 4.0) 


\section{INTRODUCTION}

Pertussis is especially most hazardous for infants under 6 months of age, which account for nearly all pertussis-related hospitalizations and deaths. On the other hand it was recognized that pertussis is grossly underreported. Global vaccination coverage with 3 doses of pertussis-containing vaccine was estimated to be $86 \%$ in $2016^{(1,2)}$. In Turkey this rate of coverage was $96 \%$ in $2017^{(3)}$. Infants whose vaccination schedule is not completed, contract the infection from their mothers and other family members ${ }^{(4)}$. In Turkey, whole cell vaccine was introduced in 1968 whereas acellular pertussis vaccine in 2008 to the Expanded Programme for Immunisation. Infants are vaccinated at 2, 4, and 6 months of age. Booster acellular pertussis vaccine is administered the age of 18 months and 6 years ${ }^{(5)}$. The routine pertussis vaccination programme is not yet implemented for pregnant women and adults. The Global Pertussis Initiative emphasized the importance and effectiveness of maternal immunization ${ }^{(6)}$. Some countries have introduced maternal vaccination programs $(7,8)$. Studies are needed about the pertussis serologic status of newly delivered mothers and their infants under 6 months of age in developing countries ${ }^{(9)}$.

The aim of this study was to assess pertussis seroprevalence in mothers and their infants at 1 month after delivery and in 6-month-old infants before they received the third dose of pertussis-containing vaccine.

\section{MATERIAL and METHODS}

This prospective, multi-centered clinical study was carried out at Well Child Outpatient Clinics of 4 hospitals between October 2013 and October 2014. Infants brought for routine well child visits were consecutively enrolled. Paired maternal and infant blood samples were obtained at the first well child visit during the first month after delivery. All women reported that they had been vaccinated against pertussis during childhood but this was not confirmed by any documentation.

The qualitative immunoenzymatic determination of Ig G-class antibodies against Bordetella pertussis was carried out by the Enzyme-Linked Immunosorbent
Assay (ELISA) technique according to the instructions of the manufacturer (GenWay Biotech, Inc, San Diego, CA, USA). The investigation covered the determination of Ig G-Class antibodies against Bordetella pertussis and Bordetella pertussis toxin. The samples were tested in duplicate. Diagnostic specificity was reported as $93.02 \%$ (95\% Cl: $80.94 \%$ 98.54\%), and sensitivity as $98.31 \%$ (95\% Cl: $90.91 \%$ 99.96\%). Inclusion criteria for the study were maternal age between 18 and 45 years and infant gestational age of 37 to 42 weeks. The exclusion criteria included history of premature or low birth weight, acute or chronic illness, transfusion of blood and/or blood product(s). Demographic characteristics such as maternal age, infant gestational age, birth weight, mode of delivery, gender of the study participants were recorded.

Blood was drawn from 209 mother-infant pairs during the first month after delivery and from 164 infants at 6 months of age before the administration of the third dose of DTaP-IPV-Hib vaccine (Figure 1). The vaccines were all administered at the Well Child Clinic. The samples were centrifuged and stored at $-20 \mathrm{C}$ until analyzed at Istanbul University Virology and Immunology Department Laboratory. The results were classified as negative and positive based on the cut-off values of the manufacturer's kit. Bordetella pertussis-lgG titers of positive serum samples were recorded. Mother-infant pairs were categorized into seronegative versus seropositive groups based on their antibody titers. Vaccine-associated seroconversion was defined as the change from seronegative to seropositive.

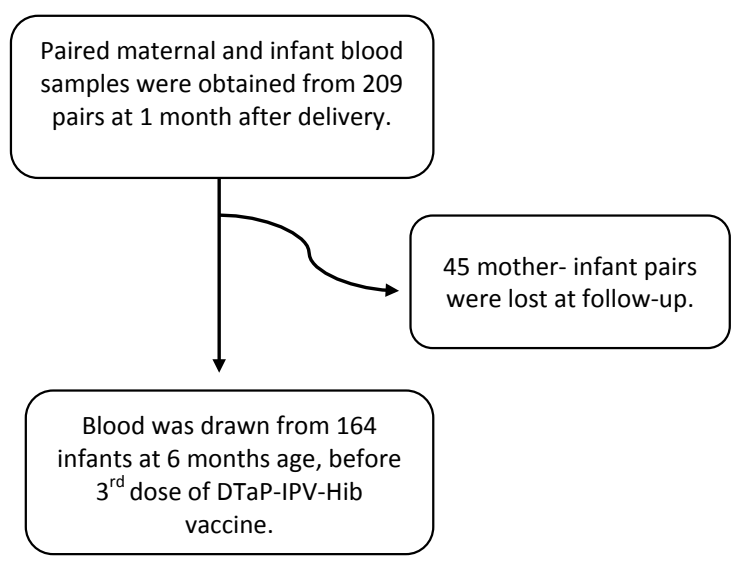

Figure 1. Flowchart of the study population. 
Ethical approval and necessary institutional permissions were obtained for the study (05/24/2013 No:10). All mothers provided written informed consent prior to enrollment.

Statistical analyses were performed using the SPSS software version 21 . The univariate analyses to identify variables associated with immune response were performed using Chi-square, Fisher exact, Student's t and Mann-Whitney U tests, where appropriate. For the multivariate analysis, the possible factors identified with univariate analyses were further entered into the logistic regression analyses to determine independent predictors of immune response. Continuous variables were presented as means with standard deviations or confidence intervals where applicable. Categorical variables were presented as numbers with corresponding percentages. Pearson correlation coefficient was used to assess the relationship between maternal and infant serum Bordetella pertussis-IgG concentrations.

\section{RESULTS}

Two hundred and nine mother-infant pairs were eligible for the study. None of the mothers were vaccinated against pertussis either during pregnancy or within the previous 5 years. No participants reported a recent history of pertussis disease, or known pertussis exposure at the beginning or during the follow-up period. Of all deliveries, $44.5 \%$ were normal vaginal delivery and $50.2 \%$ of infants were female. Mean ( \pm SD) birth weight of infants were $3337 \pm 375$ grams. The mean $( \pm S D)$ gestational age of infants was $38.7 \pm 1$ weeks and maternal age was 29.6 \pm 6.2 years.

Seroprevalence rates of Bordetella pertussis-IgG up to 1 month postpartum were $49.7 \%$ (104/209) in mothers and $32.1 \%(67 / 209)$ in infants. Of babies born to seropositive mothers, $46.2 \%$ (48/104) were Bordetella pertussis-IgG seronegative. A significant positive correlation was observed between maternal and infant Bordetella pertussis-IgG status at 1 month postpartum ( $p<0.001, r=0.600)$.

Forty-five infants were lost at follow-up and serum samples of 164 infants were evaluated at 6 months of age (Figure 1). At Table 1, the distribution of sero- positivity rates of mother-infant pairs at one month after delivery is given in Table 1.

After receiving 2 documented doses of pertussiscontaining-vaccines at 2 and 4 months of age, $56.7 \%$ $(71 / 164)$ of the infants were seropositive for Bordetella pertussis-IgG (Table 1). Out of total seropositive 71 infants, twenty-two (13.4\%) continued their prevaccination immunity. When we exclude the cases that were lost at follow-up; seronegative infants showed seroconversion after the vaccination. This difference between seronegative and seropositive infants was statistically significant $(p<0.001)$. Of 113 seronegative infants at one month 49 became seropositive after two doses of pertussis-containing vaccine. According to the definition used in this study, vaccine-associated response after two doses of pertussis vaccine was $43.4 \%$. This figure could be slightly underestimated because we could not identify the seroconverted babies among 22 infants who were seropositive at the beginning and also at the end of the study after administration of two doses of vaccine. Some of these infants might also be converters after the vaccination.

Table 1. Serology of mother-infant pairs followed until 6 months ( $n=164)$.

\begin{tabular}{lcccc}
\hline & & $\begin{array}{c}\text { Seronegative } \\
(\%)\end{array}$ & $\begin{array}{c}\text { Seropositive } \\
\mathbf{n}(\%)\end{array}$ & $\begin{array}{c}\text { Total } \mathbf{n} \\
(\%)\end{array}$ \\
\hline $\begin{array}{l}\text { One month } \\
\text { after delivery }\end{array}$ & $\begin{array}{c}\text { Mother } \\
\text { Infant }\end{array}$ & $\begin{array}{c}77(47) \\
113(68.9)\end{array}$ & $\begin{array}{c}87(53) \\
51(31.1)\end{array}$ & $164(100)$ \\
At 6 months & Infant & $93(56.7)$ & $71(43.3)$ & $164(100)$ \\
\hline
\end{tabular}

When we compared the vaccine-associated seropositivity in babies at 6 months according to maternal serology, seroconversion was observed in $48.3 \%$ $(42 / 87)$ of babies who were born to seropositive mothers and this rate was $37.7 \%(29 / 77)$ in babies born to seronegative mothers. The difference was not statistically significant $(p=0.170)$.

At 6 months, vaccine-associated seroprevalence was 2 times higher in boys (OR 2.1, 95\% Cl: 1.09-4.12). This difference was statistically significant $(p<0.026)$. Gender was entered into logistic regression for vaccine-associated response at 6 months and remained statistically significant ( $p=0.019 ; \mathrm{RR}: 2.2$ with $95 \% \mathrm{Cl}$ : 1.07-4.55). 


\section{DISCUSSION}

In our study, Bordetella pertussis-IgG seroprevalence rates were $49.7 \%$ in mothers and $32.1 \%$ in infants up to one month after delivery. After two doses of pertussis vaccine, $56.7 \%$ of the infants were still seronegative at 6 months. When vaccine-associated seroprevalence was considered, only $43.4 \%$ of infants had seropositivity after two doses of TDaP-IPV-Hib vaccination. The study demonstrated a low level of seropositivity against $B$. pertussis in mothers, which may increase the risk of pertussis in very young infants. Thus the greatest risk of morbidity and mortality from pertussis infection is among infants who are below 6 months of age and yet more than half of the babies in our study were susceptible to pertussis ${ }^{(1)}$. It is suggested that maternal pertussis antibodies protect the infants from pertussis by passive immunity. In a study of Turkish mothers where maternal and cord blood levels of anti-pertussis toxin were detected, only 34,6 $\%$ of infants had protective levels of antigens against pertussis ${ }^{(10)}$. Similarly, our results showed that only $32 \%$ of the infants have been protected, leaving the majority of infants unprotected to pertussis infection.

Either vaccination of the mothers during pregnancy or accelerated immunization of the infants for pertussis is a proposed strategy in preventing infant pertussis. Pertussis vaccination during pregnancy has already been shown to be effective in achieving higher pertussis antibody concentrations in infants and it has been introduced in several countries. However due to economic costs; universal vaccination of mothers during pregnancy cannot be covered at the moment. So, accelerated vaccination of infants for pertussis may be beneficial. One possible strategy to address this might be revisiting the current infant TDaP-IPV-Hib primary immunization schedule in Turkey. In the United Kingdom, pertussis vaccine is given when infants are 8, 12 and 16 weeks old ${ }^{(11)}$. In Netherlands, TDaP-IPV-Hib vaccine is administered at 3,5 and 11 months of age. If the mother was not vaccinated against pertussis during pregnancy then her infant receives an extra vaccination at the age of 2 months ${ }^{(12)}$. Current TDaP-IPV-Hib vaccine administrations are at 2,4,6 months in Turkey and may be that regimen needs to be changed to $2,3,4$ or $2,3,5$ months in order to immunize against pertussis at an earlier age. If one assumes that acceptable level of immunity is reached 1 month after the third injection, then infants younger than 5-7 months become at least partly susceptible to pertussis ${ }^{(7)}$.

It is suggested that the effectiveness of the first dose of vaccine varies between $62 \%$ to $68 \%$ in infants under 6 months of age, and effectiveness increases with subsequent doses (13-15). However, our study results showed that seropositivity is achieved in only $43.3 \%$ of the infants after two doses of the vaccine. The lower efficacy of the vaccine observed in our study should be explored in future studies.

Maternal passive immunity may affect infants' immune response to vaccination. Maternal antibodies can interfere with the immune response to vaccination, a phenomenon known as "blunting" (16). In this study, seroconversion rate among babies at 6 months of age was not statistically significant according to maternal serology. Yet, we can assume that maternal immunity did not affect immune response to vaccination in our study.

Conflicting findings are reported about gender difference for pertussis seropositivity ${ }^{(17,18)}$. In the current study, we found out that vaccine immune response positivity was seen 2 times more in boys in univariate analysis. In a study conducted in Turkey, geometric mean titers were also statistically higher in boys ${ }^{(19)}$. Underlying immunological differences between gender may also result in differential immune responses to vaccination. In a Dutch study, pertussis vaccine immunity did not reportedly differ between genders ${ }^{(20)}$. Fischinger et al. stated that sex differences have been noted in quality of vaccineinduced immune response to MMR and DTP across the sexes ${ }^{(21)}$. This finding should be explored in future studies.

\section{Limitations of the study}

There are some limitations of our study. Cord blood samples of infants were not available. The pertussis serology was measured by the determination of Ig G-Class antibodies against Bordetella pertussis and Bordetella pertussis toxin. Antibodies for filamentous hemagglutinin, pertactin, and fimbriae were not measured. On the other hand, our findings shed light for future studies and changes in immunization schedule of infants. 


\section{CONCLUSION}

Maternal pertussis seropositivity and infant protection by passive immunity was low suggesting maternal pertussis immunization should be considered in addition to the existing tetanus maternal immunization programme in Turkey ${ }^{(12,22)}$. Cocooning strategy may be suggested to parents who cannot receive pertussis vaccine during pregnancy ${ }^{(23)}$.

After 2 doses of DTaP-IPV-Hib more than half of the infants at 6 months of age were found to be Bordetella pertussis-Ig $\mathrm{G}$ seronegative. An alternative accelerated vaccine strategy, changing the immunization timeline for DTaP-IPV-Hib vaccination may be an option for protection of infants against pertussis.

Ethics Committee Approval: Approval was obtained from the Istanbul Medical Faculty Clinical Research Ethics Committee (05/24/2013 No: 10$)$.

Conflict of Interest: The authors declared no conflict of interest.

Funding: The study was funded by Istanbul University, Scientific Research Projects Committee (number 35513).

Informed Consent: All mothers provided written informed consent prior to enrollment.

\section{REFERENCES}

1. World Health Organization. Pertussis vaccines: WHO position paper. Wkly Epidemiol Rec. 2015;90:433-58.

2. World Health Organization. Immunization, Vaccines and Biologicals. Pertussis. 2018. Available from: http://www.who.int/ immunization/monitoring_surveillance/burden/vpd/surveillance_type/passive/pertussis/en/ (Accessed April 12, 2020.)

3. Bora Başara B, Soytutan Çağlar I, Aygün A, Özdemir TA, (editors). Prevention of disease and protection of health. Health statistics yearbook 2017. General Directorate of Health Information Systems, Turkey Ministry of Health, Ankara, Turkey: Kuban Matbaacılık Yayıncılık; 2018. p. 77. Available from: https://www.saglik.gov.tr/TR,52696/saglik-istatistikleriyilligi-2017-yayinlanmistir.html (English edition is avaliable. Accessed April 12, 2020.)

4. Wiley KE, Zuo Y, Macartney KK, McIntyre PB. Sources of pertussis infection in young infants: a review of key evidence informing targeting of the cocoon strategy. Vaccine. 2013;31(4):618-25. https://doi.org/10.1016/j.vaccine.2012.11.052

5. Özbek ÖA, Öktem IMA, Hekimoğlu CH, Sekreter Ö, Emek M, et al. Seroprevalence of pertussis toxin antibody in Manisa province of Turkey, after six years implementation of acellular pertussis vaccine. Mikrobiyol Bul. 2018;52(2):180-9. https://doi.org/10.5578/mb.57534

6. Forsyth K, Plotkin S, Tan T, Wirsing von König CH. Strategies to decrease pertussis transmission to infants. Pediatrics. 2015;135(6):e1475-82.

https://doi.org/10.1542/peds.2014-3925

7. Amirthalingam $\mathrm{G}$, Campbell $\mathrm{H}$, Ribeiro S, Fry NK, Ramsay M et al. Sustained Effectiveness of the Maternal Pertussis Immunization Program in England 3 Years Following
Introduction. Clin Infect Dis. 2016:63(Suppl. 4):S236-S243.

https://doi.org/10.1093/cid/ciw559

8. Gkentzi D, Katsakiori P, Marangos M, Hsia Y, Amirthalingam G, et al. Maternal vaccination against pertussis: a systematic review of the recent literature. Arch Dis Child Fetal Neonatal Ed. 2017;102(5):F456-63. https://doi.org/10.1136/archdischild-2016-312341

9. Fallo AA, Neyro SE, Manonelles GV, Lara C, Hozbor D, et al. Prevalence of pertussis antibodies in maternal blood, cord serum, and infants from mothers with and those without tdap booster vaccination during pregnancy in Argentina. J Pediatric Infect Dis Soc. 2018;7(1):11-7.

https://doi.org/10.1093/jpids/piw069

10. Türkoğlu E, Sönmez C, Özer E, Çöplü N, Kurugöl Z. Low pertussis antibody levels in maternal and umbilical cord blood samples in Turkey. Turk J Pediatr. 2016;58(6):573-8. https://doi.org/10.24953/turkjped.2016.06.001

11. United Kingdom National Health Services. NHS Vaccinations. 6-in-1 vaccine overview. Available from: https://www.nhs.uk/ conditions/vaccinations/6-in-1-infant-vaccine/ (Accessed April 12, 2020.)

12. Dutch National Immunisation Programme. Available from: https://rijksvaccinatieprogramma.nl/english (Accessed April 12, 2020.)

13. Campbell H, Amirthalingam G, Andrews N, Fry NK, George RC, et al. Accelerating control of pertussis in England and Wales. Emerg Infect Dis. 2012;18(1):38-47. https://doi.org/10.3201/eid1801.110784

14. Juretzko $P$, von Kries $R$, Hermann $M$, Wirsing von König $C H$, Weil J, et al. Effectiveness of acellular pertussis vaccine assessed by hospital-based active surveillance in Germany. Clin Infect Dis. 2002;35(2):162-7. https://doi.org/10.1086/341027

15. Quinn HE, Snelling TL, Macartney KK, Mclntyre PB. Duration of protection after first dose of acellular pertussis vaccine in infants. Pediatrics 2014;133(3):e513-9. https://doi.org/10.1542/peds.2013-3181

16. Bento Al, Rohani P. Forecasting epidemiological consequences of maternal immunization. Clin Infect Dis. 2016;63(Suppl. 4):S205-S212. https://doi.org/10.1093/cid/ciw557

17. Mattoo S, Cherry JD. Molecular pathogenesis, epidemiology, and clinical manifestations of respiratory infections due to Bordetella pertussis and other Bordetella subspecies. Clin Microbiol Rev. 2005;18(2):326-82.

https://doi.org/10.1128/CMR.18.2.326-382.2005

18. Kilgore PE, Salim AM, Zervos MJ, Schmitt HJ. Pertussis: Microbiology, disease, treatment, and prevention. Clin Microbiol Rev. 2016;29(3):449-86 https://doi.org/10.1128/CMR.00083-15

19. Inandi T, Guraksin A, Hacialioglu N. Seroprevalence of pertussis among children in Eastern Turkey. Public Health. 2005;119(6):550-5. https://doi.org/10.1016/j.puhe.2004.08.018

20. Boef AGC, van der Klis FRM, Berbers GAM, Buisman AM, Sanders EAM, et al. Differences by sex in IgG levels following infant and childhood vaccinations: An individual participant data metaanalysis of vaccination studies. Vaccine. 2018;36(3):400-7. https://doi.org/10.1016/j.vaccine.2017.11.070

21. Fischinger S, Boudreau CM, Butler AL, Streeck H, Alter G. Sex differences in vaccine-induced humoral immunity. Semin Immunopathol. 2019;41(2):239-249. doi: 10.1007/s00281018-0726-5. https://doi.org/10.1007/s00281-018-0726-5

22. Türkiye Cumhuriyeti Sağlık Bakanlığı, Halk Sağlığı Genel Müdürlüğü. Aşı Portalı. Yetişkin Aşılama. Available from: https://hsgm.saglik. gov.tr/depo/mevzuat/genelge/1117gbpgenelge2008pdf.pdf (Accessed April 12, 2020.)

23. Rowe SL, Tay EL, Franklin LJ, Stephens N, Ware RS, et al. Effectiveness of parental cocooning as a vaccination strategy to prevent pertussis infection in infants: A case-control study. Vaccine. 2018;36(15):2012-2019. https://doi.org/10.1016/j.vaccine.2018.02.094 